\title{
Daily Occurrence in Boris Ekimov's Stories
}

\author{
Anna V. Frolova* \\ Voronezh State University \\ 1 Universitetskaya pl., Voronezh, 394018, Russia
}

Received 20.01.2017, received in revised form 25.02.2018, accepted 07.03.2018

Boris Ekimov's stories of the 2000s which formed the collection "Saturday of Souls" are analyzed in the present article. The writer doesn't set the purpose to recreate peasants' Atlantis but perceives today of the village as a reality in which a person lives.

The concepts of "daily life" and "daily occurrence" are differentiated in the article as the ones that have different extension and occur at different times. Daily life is classified as sacral, it is one of the manifestations of existence, while daily occurrence assumes an appeal to the private life of an ordinary person in the present and his/her inclusiveness into the civilized everyday life.

The study of the everyday life of B. Ekimov's characters that allowed him to describe the current state of the village, which is characterized by the daily life coordinates reduction, has become the purpose of this article. The deformed connections between people in the literary world of the writer are, first of all, demonstrated in the transformation of the image of the master and changes in the character of the neighborhood relations.

Keywords: daily occurrence, daily life, Boris Ekimov's prose, Ekimov's character, modern village.

DOI: 10.17516/1997-1370-0231.

Research area: russian literature.

The prose by Boris Ekimov is not ignored by the literary critics. Its merits include the combination of "the increased poetic sentiment of narration with the sobriety and acuity of social vision" (Skarlygina, 1987: 228), "attention to the exact details of the life of the earth and its living world" (Bogatko, 1990: 296), interest to the "spiritually significant" (Rodnianskaia, 1996: 240), "authenticity of the depicted" and "conscientious attitude to life" (Udin, 1988: 130), "absolute truthfulness, moral purity of the author's attitude", "depictive talent" (Serdiuchenko, 2000: 95) and mythopoetics
(Kovtun, 2013: 411-427). The peculiarity of the writer's literary work is largely determined by the appeal to the topic of the modern village and the related topics of peasant labor, memory and the connection of generations, to the issues of the meaning and value of existence, life and death. Ekimov studies the history of the village from the moment of its foundation up to its collapse as if "testing out a traditional peasant way of life" (Kovtun, 2013: 326).

The collection of stories "Saturday of Souls", which included the stories of the 2000s was selected as the analytical material for the article.

(c) Siberian Federal University. All rights reserved

* Corresponding author E-mail address: frolova-anna2008@yandex.ru 
The author is interested in what changes in the modern village life are recorded by Ekimov, what the daily life of man has become.

As noted by K.A. Vorotyntseva, "the category of everyday life in the field of literary analysis is the area of intensive theoretical search" (Vorotyntseva, 2010: 276). The issues of the scope of the concept, the forms of its embodiment in fiction, as well as the issue of the relationship between the concepts of "daily occurrence" and "daily life" are under discussion. The boundaries between these terms remain movable. A number of researchers (V. Leleko, T. Volobueva) bring together the categories of "daily life" and "daily occurrence"; others (K. Vorotyntseva, T. Strukova) insist on the correspondence of these concepts based on the principle of particular ("daily life") and universal ("daily occurrence"). From the author's point of view, "daily life" and "daily occurrence" are the concepts that have different extension and occur at different times.

In the Explanatory Dictionary of V. Dal, the notion "daily life" is combined with the word "existence" in the dictionary entry "to happen, to be, being there". "Existence" is both "to be, being, creature, creation", and "subsistence, being alive, life". The meaning of the notion "daily life" is "staying" and "being, life, a kind of life, custom and habit", "everyday" - "relating to life, to a kind of life" and "describing everyday life" - "historical". (Dal, 1981-1982: vol. 1, 148). It is obvious that in the Russian people's minds the understanding of "existence" as life, and "daily life" as a kind of life, has established, and it means that daily life is one of the manifestations of existence. At the same time, in V. Dal's dictionary, "daily life" includes the possibility of the "daily occurrence" emergence in its modern understanding. The dictionary recorded a serious attitude of the people to the life order, to its normativity, which was perceived primarily as a hierarchical and value normativity. Yu.M.
Lotman continued the idea of V. Dal, but there was already less sacral meaning in the definition of daily life: "... not only the life of things, these are customs, the whole ritual of daily behavior and the order of life that determine the daily routine, the time of various occupations, the nature of work and leisure, the forms of recreation, games, love ritual and funeral rites" (Lotman, 1994: 12).

V. Dal defines everyday through a synonymic row: "daily, routine, ordinary, every-day, prosaic, common, mundane, day to day, day by day" (Dahl, 1981-1982: vol. 3, 147). It clearly shows an orientation to the repeatability and the routine of human existence. Researchers also note the material-corporal essence of daily occurrence, its attribution to the sphere of private and, therefore, significant for everyone, as well as protective function. Daily occurrence implies an appeal to the private life of an ordinary person in the ongoing present. It is dominated by pragmatics that inscribes a person into the civilizational, that is, modern practice.

The spatial dimension of daily occurrence is a place (a dwelling, a settlement) where the life of a person is taking its course. B. Ekimov records the change in the spatial coordinates of the village: "The farm had a big name - Bol'shye Chapury. <...> It used to be at the time of Soviet power, when there were collective farms and state farms, when Chapury were really big, for two hundred yards. And nowadays it is only a small settlement in the far distant Don region" (Ekimov, 2006). An important characteristic of the locus is its remoteness from the city and civilization. The farm as if excluded from the life of the big world. In this connection, the poems by Nikolay Rubtsov "Kind Filya" and "In the Izba" are recalled. They are characterized by the same artistic space ("farmstead in the forest" and "the small log house behind the hill"), the main quality of which is remoteness and solitude: "between the deer paths", "far from all the global 
affairs". The world, described in the poems, is not connected with the progress, the achievements of civilization and even the elementary everyday amenities. At the same time, the protagonists are characterized by the seamless relationship with the world, the fullness of personal existence in harmony with the surrounding. In N. Rubtsov's poems remoteness of the farmstead from the civilization is a condition of the closed nature and secrecy of the world, while in B. Ekimov's stories it becomes a sign of the substandard living conditions in the modern village. Its essential characteristic is desolation and wildness: "People die, people leave the farm, houses and facilities become shabby and collapse, dilapidating the former crowded yards" (Ekimov, 2006). There is the meaning of potential fullness in the semantics of "emptiness", however, it is not actualized in the stories by B. Ekimov. More than that, the loss of not only houses and estates, but also buildings of the later times marking the Soviet era, are revealed: "Once a school, a shop, a post office, a club, a medical centre and the brigade office were squeezed here. And nowadays - ruins and wastelands with covered pits" (Ekimov, 2006).

Returning to the phrase "Bol'shye Chapury", it is worth noting that B. Ekimov "works" with the definition, and not with the main word. According to the dictionary of V. Dal, chapura is heron, which in various mythologies is a symbol of ancestors, revival and the guardian of the traditions, associated with the solar symbol (Dal, 1981-1982: vol. 4, 582). Thus, already in the name of the farm, the writer brings together the former daily life with the present daily occurrence, designating the village's movement from the past to the present. "The task of the writer is to study the ways of survival for the people under the conditions of the destruction of the global myth about the selectness of the Russian land, the single national house-temple" (Kovtun, 2013: 339).
Its separation into individual loci also becomes the sign of the changing space. B. Ekimov compares the houses and farmsteads with the "floating islands". People live on the farm not together, but next to each other. The change in the nature of neighborly relations is an evidence of the contemporary daily occurrence triumph. Dictionary by S.I. Ozhegov gives the following definition to the neighborhood: "contiguity, proximity to anyone or anything in the place of residence or location" (Ozhegov, 1999: 750). Neighborhood is inscribed in the Russian culture and a well-mastered folklore concept. The indicator of this is a lot of sayings about neighbors where the meanings of kinship and domestic bliss are actualized, and that goes beyond the dictionary meaning of the word ("I can live without my brother, but I cannot live without a neighbor", "There will not be peace if a neighbor does not want", "It is a bad thing to offend a neighbor", etc.)

The phenomenon of neighborhood becomes an object of the author's reflection in the story "Just - Neighbors". It is based on the antithesis: the former, already dead neighbors of the narrator and the present ones are opposed. B. Ekimov indicates different quality of human relations. Former neighbors are as family members, they are sympathetic, hospitable, share misfortunes and joys, they know the art of shared households (they live in accordance with the principle: it is better to hurt themselves than to harm the neighbor) and they are included into the space of the house. New neighbors build a pigsty away from their home, but in the immediate vicinity of the neighbors' fence, do not go out to find out why neighbors have light at night, although this seems suspicious. "Solid fences and iron grids" indicate of reluctance to live a common life, which is manifested even in the violation of the ritual of communication: "The usual word "hello" becomes a rarity" (Ekimov, 2006). 
It becomes clear that the people's tradition of understanding neighborhood, as a certain way of life implementation, has become a thing of the past. They have been replaced by social relations, which change and deform former neighbors and former requirements of daily life.

The theme of rural desolation, impoverishment of the village and degradation of its inhabitants is, perhaps, the key one in the creative work of Boris Ekimov. In the literary world of the writer, a person is on the verge of survival, what is motivated by the change in the historically established forms of existence collective farm life that became habitual. While there was the collective farm, life was quite tolerable, a person was only required to work, the next day was clear and predictable. After the collapse of the collective farm they even forget to deliver bread to the farm. Everyone was left alone with their problems, with a range of everyday affairs. The protagonist of the story "Tyurin" painfully experiences his own lack of demand, repeatedly telling the same "sweet tale of bygone days" about his past life, when his work was appreciated. B. Ekimov's characters yearn not for ontological senses, the collective farm for them replaces the sacred whole.

Labour is proclaimed as the main value of the farm life in the literary world of B. Ekimov. Researchers have long specified a typical character of Ekimov's prose - a rural worker who has worked on earth all his life, and everyday duties for him is not a burden, but they become a natural and necessary need. Labour for him is fulfillment of the main mission, the main meaning of life. This life philosophy finds its expression in the specific sense of the Master, which basis is the knowledge of his own responsibility to everything that lives on earth. "The word master in B. Ekimov's words", writes V. Vasiliev, "is the highest assessment of man and his relation to the environment ..." (Vasiliev, 1988: 153).
In several stories from the collection "Saturday of Souls" the main characters are Timofey and Valentina - a married couple who came back from the city to the village. Their farmstead stands for a sacral center: it is located "in the middle of the farm", "like a navel, you cannot walk it by and pass it by". It is the embodiment of the village style: buildings - a family brick lined house, a brick garage with a spacious cellar, a residential kitchen, banya and household outbuildings are "reliable and strong", a lot of cattle and a well-groomed garden. The characters are included into the daily cycle of affairs as a natural way of life actualization. Hard labour is assessed by the characters as a heavy one, but familiar, they are not bothered by it, and grumble, mostly, out of habit. The way of the characters' life embodies the peasant idea of life on earth, which always feeds and brings back to the notion of daily life as a worldly, moral and convenient for people order.

At the same time, the word "master" gets a different meaning, motivated by the present day. Not only Timofey, but Chechen Musa, who bought up the whole village, as well as Mishka Abrek are characterized with it by B. Ekimov. The source of the organized life of the latter is not only the readiness to work hard, but also the absence of moral barriers: "day and night the stream flows from the moonshine still", the character has no morals in taking stolen things, "evaluating everything in a kopeck". A good night for Mishka is when the cow calved with twins, and when a neighbor brought a golden ring to sell to him to buy some alcohol. Thus, there is a new twist in the motive of management: the master is not only the one who works hard on the earth, but also an enterprising person, able to settle down in life.

At the other pole of the story there are characters who do not know how or do not want to get their daily life going. Unattractiveness of their lives is emphasized in the stories: "Grishka 
Bakhchevnik's hut is like a fox burrow: dark, with always closed shutters and yellow electric light, with a sour smell of home brew and a dirty dwelling" (Ekimov, 2006), Vaska Rakhman has "the blackened from clapboard house with holes and slots, with a broken brick chimney and ruins of the porch" (Ekimov, 2006). These substandard living conditions that emerged a long time ago demonstrate that the conflict marked by Ekimov is moral and long-standing. If there were no such Bakhchevnikovs and Rakhmanovs, then today's havoc would not exist. Rakhmanov's house, as well as Timofey and Valentina's farmstead, is compared by B. Ekimov with the navel, but actualizes another meaning of the word: extreme poverty: "There is nothing around: no front garden, no fence, no feeble small garden and, all the more, neither tree nor bush" (Ekimov, 2006). At the same time, Rakhmanov's "crow's nest" also claims to the place of the sacral center of the farm. B. Ekimov, thus, shows a multicomponent village life in which the polar images of life order, evaluated by the participants as self-sufficient, coexist. Moreover, the quantitative ratio is not in favor of workers.

A striking feature of B. Ekimov's style is the power of observation, loyalty to the "truth of life", attention to details and ins and outs of daily life. The details reflect the life style of the farm, modern and lost. Thus, Russian stoves were replaced by ovens, previously the family gathered at the table for a meal, and now they drink moonshine. If returning to the old way takes place, it happens not by choice. Several habitual details that highlight the lifestyle have been lost: "Little by little, the benches in the streets near the gates, where on summer evenings people were sitting in the twilight with their neighbors, have disappeared" (Ekimov, 2006). B. Ekimov shows that in the modern village household items and things have lost their symbolic significance that connected them with the ultimate values.

The title of the collection of stories refers to the spiritual line - the folk tradition. Saturday of Souls is a ritual, and therefore, a household celebration. In the church calendar that regulated the life of the traditional Russian family, its frequency and different names, covering all the needs of human life, are noted. The ritual aspect of the holiday rituals associated with food, visiting the cemetery, etc. is well preserved. Saturday of Souls mostly fall on the time of fasting, which gives an opportunity to speak of them not only as a commemoration of those who passed away, but also as the time for spiritual purification and rethinking life.

The modern village in B. Ekimov's stories is not a comprehensive and complete existence, the author does not set the task of recreating it, he wants to comprehend today's life as a reality. In his literary world ontological coexists with historical and social, and daily life with daily occurrence. B. Ekimov records changes in the life of the village. On the one hand, "the old house is disappearing $<\ldots>$ along with the whole district", and on the other hand "different people appear", "children's voices ring and ring". In the context of the collection of stories it is permissible to talk not about trying to reconstruct the former way of life, but rather about reflections on tomorrow, about what the life of the village will be like: in the triumph of everyday life, or "Saturday of Souls" will also remain?

\section{References}

Bogatko, I.A. (1990). Predchuvstvie: Literaturno-kriticheskie stat'i i ocherki [Presentiment: Literary Criticism and Essays]. Moscow, Sovremennik, $301 \mathrm{p}$.

Dal, V.I. (1981-1982). Tolkovyi slovar' zhivogo velikorusskogo iazyka: v 4 t. [Explanatory Dictionary of the Living Great Russian Language: In 4 vol.]. Moscow, Russkii iazyk. 
Ekimov, B.P. (2006). Roditel'skaia subbota (rasskazy raznyh let) [The Saturday of Souls (Stories of Different Years)]. Moscow, Roman-gazeta, 15, $136 \mathrm{p}$.

Kovtun, N.V. (2013). The Fate of the Patriarchal Myth as Depicted by Boris Ekimov: 'Kholiusha's Yard' And 'Pinochet'. Russian Literature. Amsterdam. Lxxiii-Iii, 411-427.

Kovtun, N.V. (2013). Sovremennaia traditsionalistskaia proza: ideologiia i mifopoetika [Modern Traditionalist Prose: Ideology and Mythopoetics]. Krasnoyarsk, Sibirskii Federal'nyi Universitet, $352 \mathrm{p}$.

Lotman, Yu.M. (1994). Besedy o russkoi kul'ture: Byt i traditsii russkogo dvorianstva (XVIIInachalo XIX v.) [Conversations about the Russian Culture: Daily Life and Traditions of the Russian Nobility (18 ${ }^{\text {th }}$ - Early 19 $9^{\text {th }}$ Century)]. St. Petersburg, Iskusstvo-SPB, 398 p.

Ozhegov, S.I, Shvedova, N.Yu. (1999). Tolkovyi slovar' russkogo iazyka: 80000 slov $i$ frazeologicheskikh vyrazhenii [Explanatory Dictionary of the Russian Language: 80000 Words and Phraseological Units]. Moscow, Azbukovnik, 994 p.

Rodnianskaia, I. (1996). Rod liudskoi [The Humankind], In Novyi mir [The New World], 3, 237-241.

Serdiuchenko, V. (2000). Russkaia proza na rubezhe tret'ego tysiacheletiia [The Russian Prose at the Turn of the Third Millennium], In Voprosy literatury [The Issues of Literature], July-August, 77-97.

Skarlygina, E. (1987). Vse na svete zhivoe [Everything in the World is Alive], In Znamia [The Banner], 12, 228-230.

Udin, Ya. (1988). O proze B. Ekimova [About Prose of B. Ekimov], In Volga [Volga], 3, 130-141.

Vasiliev, V.V. (1988). Dostoinstvo slova: Literaturnye statji i zametki o sovetskoi poezii i proze [The Merit of Word: Literary Articles and Notes about the Soviet Poetry and Prose]. Moscow, Sovremennik, $267 \mathrm{p}$.

Vorotyntseva, K.A. (2010). Poetika povsednevnosti v aspekte deistvitel'nosti geroia [Daily Occurrence Poetics in the Aspect of Character's Reality], In Kritika i semiotika [Critique and Semiotics], Novosibirsk, 14, 276-292.

\section{Повседневность в рассказах Бориса Екимова}

\section{А.В. Фролова}

Воронежский государственный университет Россия, 394018, Воронеж, Университетская пл., 1

В настоящей статье анализируются рассказы Бориса Екимова 2000-х годов, составивших сборник «Родительская суббота». Писатель не ставит иелью воссоздать крестьянскую Атлантиду, а воспринимает сегодняшний день деревни как данность, в которой живет человек. В статье разграничиваются понятия «быт» $и$ «повседневность» как разнообъемные и разновременные. Быт отнесен к сакральному, это одно из проявлений бытия, повседневность же предполагает обращение к приватной жизни обычного человека в настоящем, его включенность в циивилизационный обиход.

Целью статьи стало исследование повседневной жизни героев Б. Екимова, позволяющей ему описать современное состояние деревни, характеризующееся редуцированностью бытийных 
координат. В художественном мире писателя деформированнье связи между людьми проявляются, в первую очередь, в трансформации образа хозяина и изменении характера соседских отномений.

Ключевые слова: повседневность, быт, проза Бориса Екимова, герой Екимова, современная деревня.

Научная специиальость: 10.01.01 - русская литература. 